\title{
調理方法の簡便化が食味に及ぼす影響 \\ 一調味の順序について一
}

\author{
松本 仲子 · 小川 久惠*
}

(*女子栄養大学短期大学部)

\section{Effect of simple and easy cooking in the method of seasoning}

\author{
Nakako Matsumoto, Hisae Ogawa* \\ *Junior Callege of Kagawa Nutrition University, 3-24-3 Komagome, Tosima-ku, Tokyo, 170-8481 \\ 干170-8481 東京都豊島区駒込 3-24-3
}

\begin{abstract}
When seasoning nimono ${ }^{1}$, it is considered best to add sugar, salt and shōyu in that order. To simplify preparations, however, it is possible to combine these seasonings and add them all at once. Ten different kinds of nimono using both this method and the traditional order preservation method were prepared and compared using the sensory evaluation method. The following results were obtained.

Looking at potato, taro, pumpkin, eggplant, lotus root, bamboo shoot, dried daikon, hijiki seaweed and pork belly nimono dishes, no difference was detected between the two seasoning methods. In the case of scarlet runner beans, it was gauged that preserving the order set down for the addition of seasonings resulted in a slightly better result than was seen when the seasoning were added all together. It could be suggested that this was due to the appearance of the dish being significantly better when the seasoning order was preserved.
\end{abstract}

\section{はじめに}

生鮮食品の流通の迅速化, 新しい加工食品の出現, 調 理器具の改良など調理周辺の変化に加えて女性の就業や 核家族化, 高齢者家庭の増加など, 食をとりまく環境は 大きく変化している。そうしたなか, 従来の調理方法と 現在の調理条件に適する方法を比較することによって, 調理の簡便化の是非について検討してきたが，多くの料 理について両調理法の間にはほとんど差が見られなかっ た1) 9)。煮物は, 家庭の調理において減少傾向にあり10), また初心者にとって難しいと感じる料理とされる11)。そ こで煮物について，煮方をより容易に，より簡便にする 方策として調味料の加え方について検討することとした。 煮物の調味方法については一般にサシスセソの順に加え ていくのがよいとされることから, 調味料を順次加える 方法を定法，全調味料を同時に加える方法を簡便な方法 として, 官能評価法により比較し, 若干の知見が得られ たので報告する。

\section{I ．実験方法}

\section{1. 試料}

検討した料理の試料の分量, 調製方法を表 1 に示し た ${ }^{12), 13)}$ 。調味料の加え方の定法については数種の調理 書14) 18) を参考に定め, 順次に加える（以下，順次調味） と同時に加える (以下, 同時調味) の 2 方法とした。加 熱の仕方については両法ともにガスコンロで沸騰までは 時間を一定に定めて強火, 沸騰継続中は煮立つ状態が同 程度であることを目測によって確認し, 鍋の大きさや落 し蓋の使用，加熱時間などが同じになるように配慮した。 使用した材料, 調味料は東京都豊島区のスーパーマーケ ットで購入した。

\section{2. 官能評価の方法}

官能評価は外観, 香り, 味, テクスチャーおよび総合 評価を主項目として，７段階の評点評価法によった。な おそれぞれの料理で必要に応じて小項目を設けた。

試料は白血に盛り, 各料理ともに室温 $25 \pm 2{ }^{\circ} \mathrm{C}$ に放置 した温度で供し, 試食順はラテン方格に従った。 
表 1 試料調製

\begin{tabular}{|c|c|c|c|c|c|c|}
\hline & 料理名 & & 試料分量 & & 比較事項 & 調製方法 \\
\hline \multirow{2}{*}{$\begin{array}{l}W \\
\text { \& } \\
\text { 類 }\end{array}$} & じゃがいもの炒め煮 & $\begin{array}{l}\text { じゃがいも } \\
\text { 出し汁 } \\
\text { 砂糖 } \\
\text { しょうゆ } \\
\text { 油 }\end{array}$ & $\begin{array}{l}\text { じゃがいも重量の } 60 \% \\
5.8 \% \text { 糖分（砂糖 } 8: \text { みりん } 1) \\
1 \% \text { 塩分 } \\
1 \%\end{array}$ & $\begin{array}{l}900 \mathrm{~g} \\
540 \mathrm{~g} \\
46 \mathrm{~g}, \quad 17 \mathrm{~g} \\
54 \mathrm{~g} \\
9 \mathrm{~g}\end{array}$ & 順次調味 & 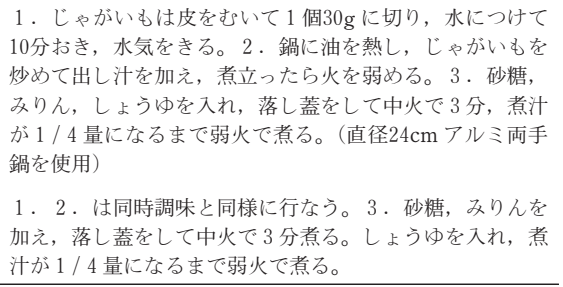 \\
\hline & さといもの含め煮 & $\begin{array}{l}\text { さといも } \\
\text { 出し汁 } \\
\text { 塩 } \\
\text { 砂糖 }\end{array}$ & $\begin{array}{l}\text { さといも重量の } 100 \% \\
1 \% \text { 塩分（塩 } 6: \text { しょうゆ } 1) \\
4 \% \text { 糖分（砂糖 } 2 \text { : みりん } 1)\end{array}$ & $\begin{array}{l}400 \mathrm{~g} \\
400 \mathrm{~g} \\
3.4 \mathrm{~g}, \quad 3.6 \mathrm{~g} \\
10 \mathrm{~g}, \quad 15 \mathrm{~g}\end{array}$ & 順次調味 & 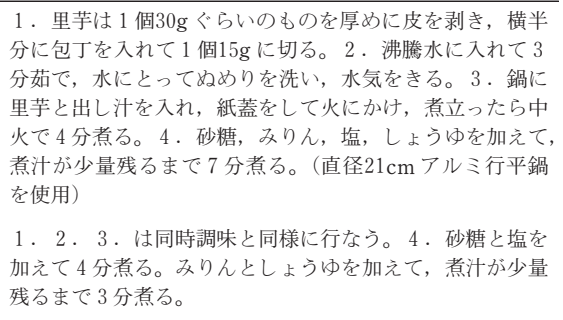 \\
\hline $\begin{array}{l}\text { 豆 } \\
\text { 類 }\end{array}$ & はなまめの煮物 & $\begin{array}{l}\text { はなまめ（乾物） } \\
\text { 水 } \\
\text { 砂糖 } \\
\text { 塩 }\end{array}$ & $\begin{array}{l}\text { はなまめ重量の } 100 \% \\
70 \% \text { 糖分 }(\text { 乾物 }) \\
1 \% \text { 塩分 }\end{array}$ & $\begin{array}{l}200 \mathrm{~g} \\
200 \mathrm{~g} \\
140 \mathrm{~g} \\
2 \mathrm{~g}\end{array}$ & 順次調味 & 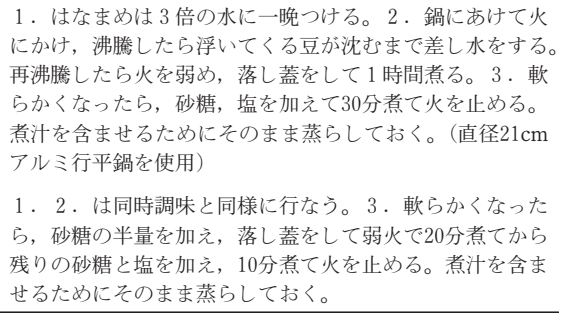 \\
\hline \multirow{5}{*}{$\begin{array}{l}\text { 野 } \\
\text { 菜 } \\
\text { 類 }\end{array}$} & かぼちの含め煮 & $\begin{array}{l}\text { かぼちゃ } \\
\text { 水 } \\
\text { 砂糖 } \\
\text { 塩 }\end{array}$ & $\begin{array}{l}\text { がほちゃ重量の30\% } \\
6 \% \text { 糖分（砂糖 } 2 ： \text { みり } 1) \\
0.8 \% \text { 塩分（塩 } 5: \text { しょうゆ } 3 \text { ) }\end{array}$ & $\begin{array}{l}900 \mathrm{~g} \\
270 \mathrm{~g} \\
36 \mathrm{~g}, \quad 54 \mathrm{~g} \\
4.5 \mathrm{~g}, \quad 18 \mathrm{~g}\end{array}$ & 順次調味 & 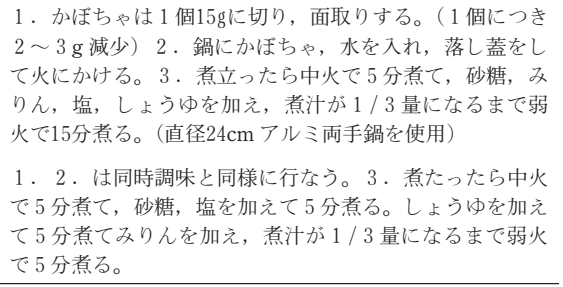 \\
\hline & なすの炒め煮 & $\begin{array}{l}\text { なす } \\
\text { 水 } \\
\text { 砂糖 } \\
\text { しょうゆ } \\
\text { 油 }\end{array}$ & $\begin{array}{l}\text { なす重量の } 70 \% \\
5 \% \text { 糖分 } \\
1 \% \text { 塩分 } \\
6.5 \%\end{array}$ & $\begin{array}{l}400 \mathrm{~g} \\
280 \mathrm{~g} \\
20 \mathrm{~g} \\
24 \mathrm{~g} \\
26 \mathrm{~g}\end{array}$ & 順次調味 & 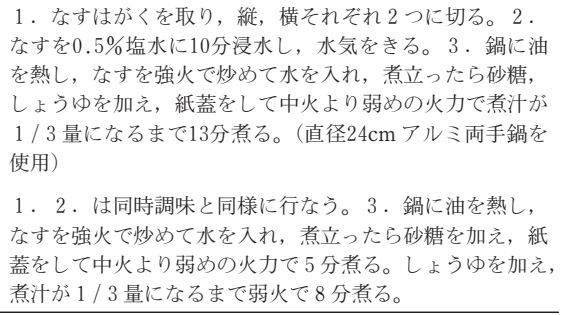 \\
\hline & れんこんの土佐煮 & $\begin{array}{l}\text { れんこん } \\
\text { 水 } \\
\text { 砂糖 } \\
\text { 塩 } \\
\text { かつ捄節 }\end{array}$ & 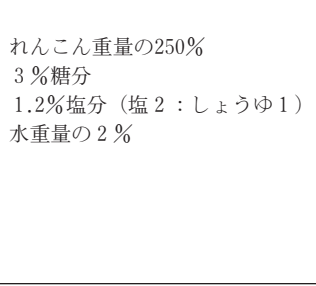 & $\begin{array}{l}500 \mathrm{~g} \\
1250 \mathrm{~g} \\
15 \mathrm{~g} \\
4 \mathrm{~g}, \quad 12 \mathrm{~g} \\
25 \mathrm{~g}\end{array}$ & 順次調味 & 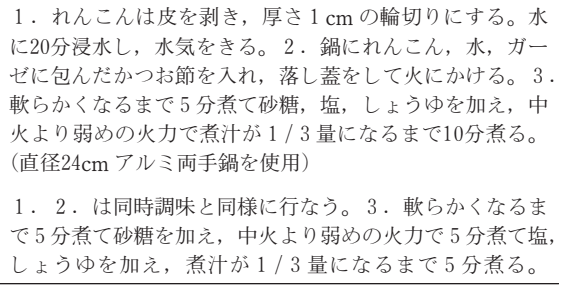 \\
\hline & たけのこの直煮 & $\begin{array}{l}\text { たけのこ（ゆでたもの） } \\
\text { 水 } \\
\text { 砂糖 } \\
\text { しょうゆ } \\
\text { かつ抄節 }\end{array}$ & $\begin{array}{l}\text { たけのこ重量の } 150 \% \\
3 \% \text { 糖分（砂糖 } 3: \text { みりん } 1) \\
1.2 \% \text { 塩分 } \\
\text { 水重量の } 4 \%\end{array}$ & $\begin{array}{l}600 \mathrm{~g} \\
900 \mathrm{~g} \\
14 \mathrm{~g}, \quad 14 \mathrm{~g} \\
43 \mathrm{~g} \\
36 \mathrm{~g}\end{array}$ & 順次調味 & 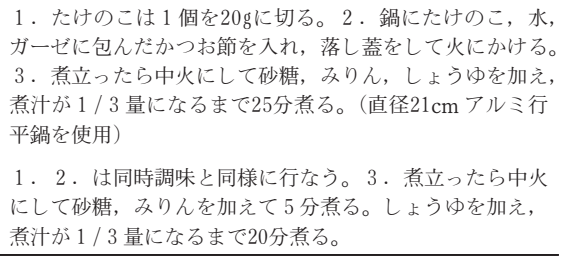 \\
\hline & 切干だいこんの煮物 & $\begin{array}{l}\text { 切干だいこん（もどした } \\
\text { 油揚げ } \\
\text { 出し汁 } \\
\text { 砂糖 } \\
\text { しょうゆ } \\
\text { 油 } \\
\text { 酒 }\end{array}$ & $\begin{array}{l}\text { こもの) } \\
\text { 切干だいこんの重量の } 150 \% \\
10 \% \text { 糖分 } \\
2 \% \text { 塩分 } \\
4.8 \% \\
17 \%\end{array}$ & $\begin{array}{l}540 \mathrm{~g} \\
90 \mathrm{~g} \\
810 \mathrm{~g} \\
54 \mathrm{~g} \\
65 \mathrm{~g} \\
26 \mathrm{~g} \\
92 \mathrm{~g}\end{array}$ & 同時調味 & 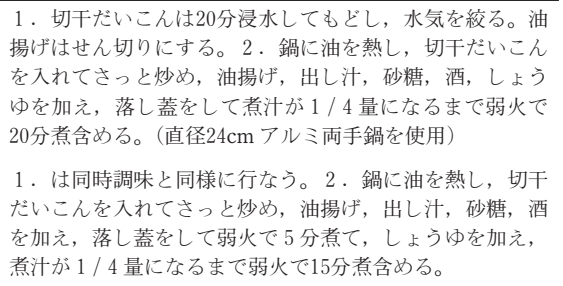 \\
\hline
\end{tabular}


日本食生活学会誌 Vol.17 No.4（2007）

\begin{tabular}{|c|c|c|c|c|c|c|}
\hline 藻 & ひじきの炒め煮 & $\begin{array}{l}\text { 芽ひじき } \\
\text { 油揚げ } \\
\text { 出し汁 } \\
\text { 砂糖 } \\
\text { しょうゆ } \\
\text { 油 } \\
\text { 酒 }\end{array}$ & $\begin{array}{l}\text { l) } \\
\text { 芽ひじき重量の } 200 \% \\
4 \% \text { 糖分（砂糖 } 3: \text { みりん } 1) \\
1.2 \% \text { 塩分 } \\
2 \% \\
5 \%\end{array}$ & $\begin{array}{l}240 \mathrm{~g} \\
90 \mathrm{~g} \\
480 \mathrm{~g} \\
7.2 \mathrm{~g}, \quad 7.2 \mathrm{~g} \\
17 \mathrm{~g} \\
4.8 \mathrm{~g} \\
12 \mathrm{~g}\end{array}$ & 同時調味 & 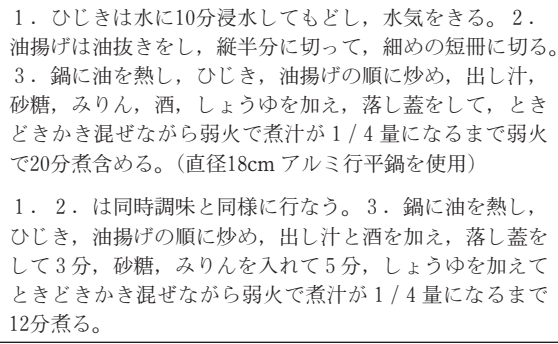 \\
\hline $\begin{array}{l}\text { 肉 } \\
\text { 類 }\end{array}$ & 豚の角煮 & $\begin{array}{l}\text { 豚ばら肉 } \\
\text { 扔から } \\
\text { 砂糖 } \\
\text { しょうゆ } \\
\text { 酒 }\end{array}$ & $\begin{array}{l}9 \% \text { 糖分（砂糖 } 5: \text { みりん } 2) \\
1.5 \% \text { 塩分 } \\
20 \%\end{array}$ & $\begin{array}{l}900 \mathrm{~g} \\
300 \mathrm{~g} \\
58 \mathrm{~g}, \quad 69 \mathrm{~g} \\
81 \mathrm{~g} \\
180 \mathrm{~g}\end{array}$ & 順次調味 & 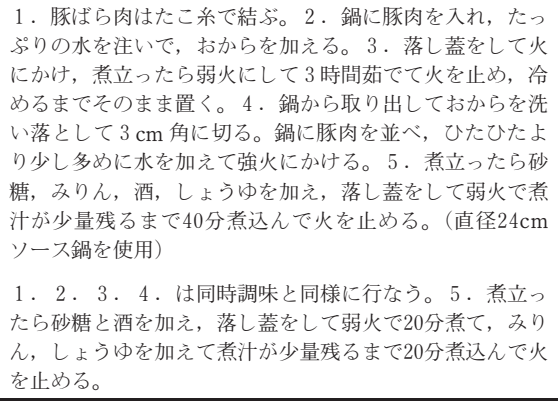 \\
\hline
\end{tabular}

*本みりんの $100 \mathrm{~g}$ 中には, 糖質 $41.9 \mathrm{~g}$ が含まれているとして, 重量換算のために 3 倍した。12)

*濃口しょうゆの $100 \mathrm{~g}$ 中には, 食塩相当量 $15.0 \mathrm{~g}$ が含まれているとして, 重量換算のために 6 倍した。13)

パネルは調理を専門職とする女子栄養大学短期大学部 調理学研究室教職員10名, および学生10名の計 20 名によ り構成した。年齢は教職員 $21 \sim 61$ 歳で平均年齢 43.5 歳, 学生21〜22歳で平均年齢21.7歳, 性別は全員女性である。

また，実験は2002～3 年，実験䛊差を考慮して 1 料理 につき 2 回ずつ繰り返して実施したが，同一傾向の結果 が得られなかった場合については 3 回実施し，傾向が類 似した 2 データーを用いて集計した。官能評価の集計は, はなまめについては 2,3 回目の評価結果, その他につ いては 1, 2 回目の評価結果を教員, 学生の別に平均值 を求め, 教員, 学生の評価を比較した。その結果殆どの 項目について有意差はみられなかったので, 次に教員, 学生の評価を合わせた平均值を求めて, 結果を図示した。

以下，本文中に示す点数は， $+3=$ 非常に良い（また は非常に硬い, 非常に味がしみているなどの強弱), 0 =普通， -3 =非常に悪い（または非常に軟らかい，非 常に味がしみていないなどの強弱）を尺度とした。

\section{II. 官能評価結果}

\section{1) じゃがいもの炒め煮}

官能評価の結果を図 1 に示した。色の濃さの強弱にお いて，同時調味がやや色が濃いと判断されたが，外観の 総合評価では有意差は認められなかった。他の大項目, 小項目ともに有意差は認められなかった。総合評価值は 順次調味 0.3 に対して, 同時調味は 0 で普通と評価され ており，調味料を一度に加える同時調味で差し支えない と考えられた。

\section{2 ) さといもの含め煮}

官能評価の結果を図 2 に示した。テクスチャーの硬さ, 粘り感の強弱に捛いて両者の評価がほぼ同じであったほ かは，全ての項目で順次調味が同時調味より高く評価さ

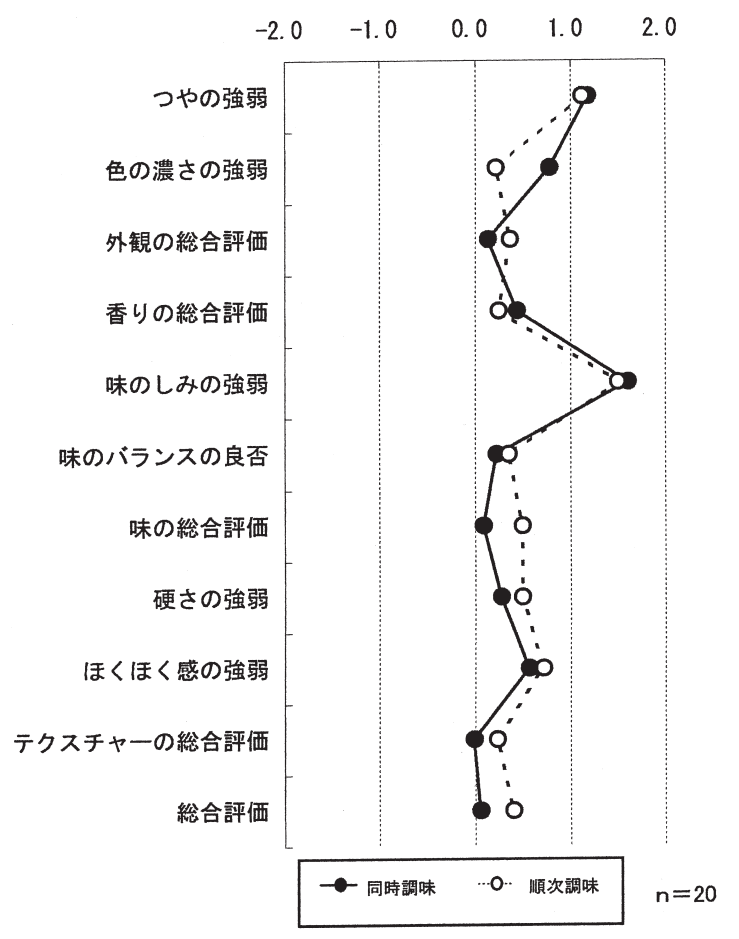

図1 じゃがいもの炒め煮

れた，しかしその差は評点で 0.5 以下と僅少で，いずれ も有意差は認められなかった。総合評価は順次調味 0.2 に対して, 同時調味は 0 で普通と評価されており, 同時 調味で差し支えないと考えられた。

\section{3 ) はなまめの煮物}

官能評価の結果を図 3 に示した。順次調味は同時調味 に比較して, つやの強弱に扔いて $1 \%$, 色の濃さの強弱 において $5 \%$ の危険率でそれぞれ強いと評価されたが， 外観の総合評価には有意差はみられなかった。またその 他の項目に抢いては有意差はみられないが，順次調味が 


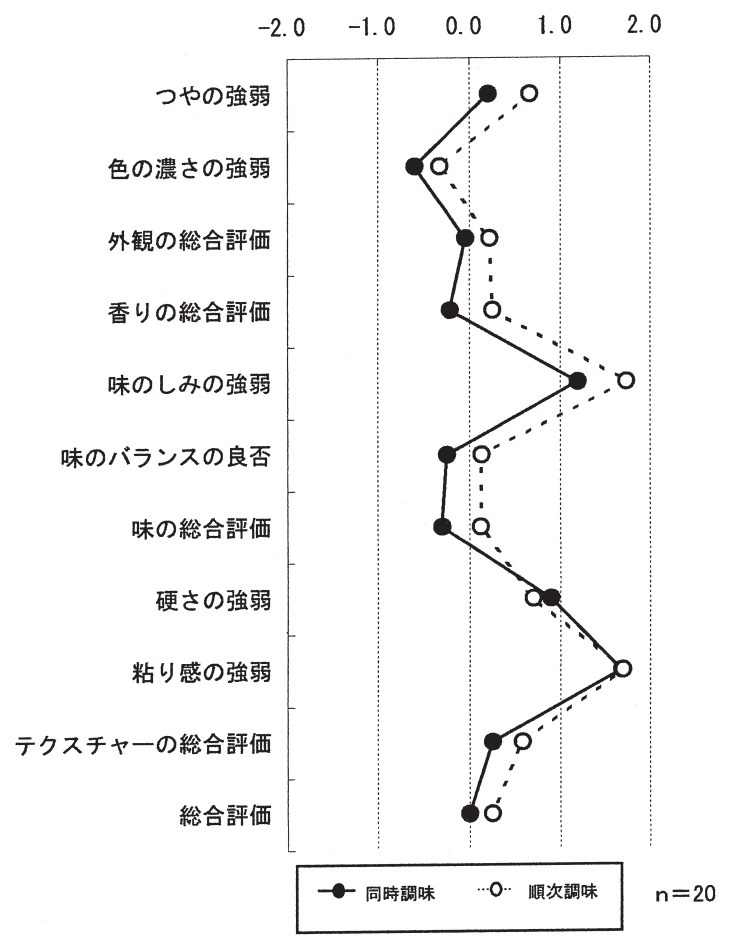

図 2 さといもの含め煮

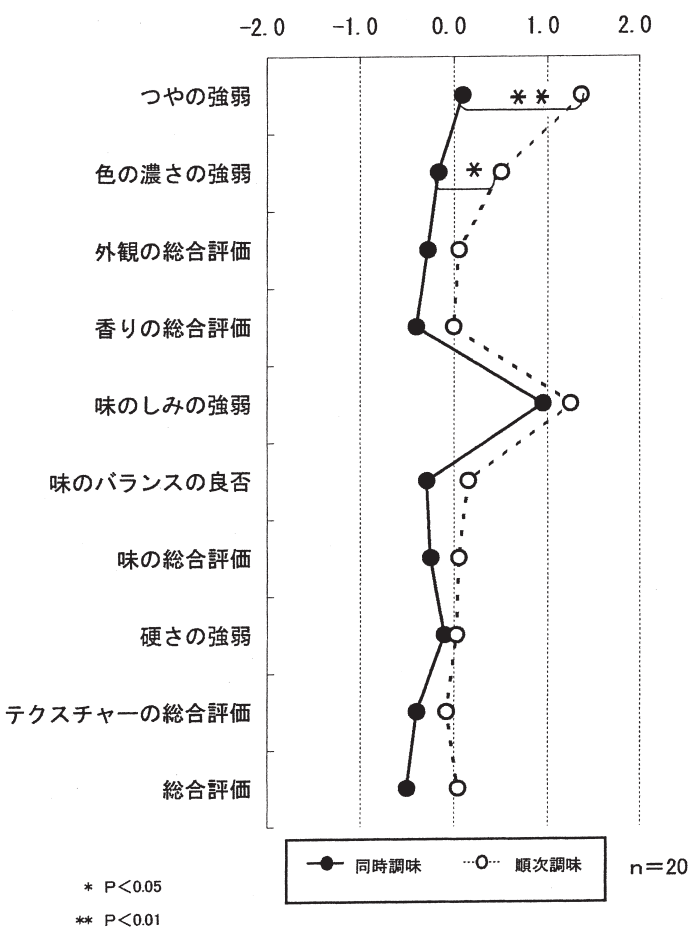

図 3 はなまめの煮物

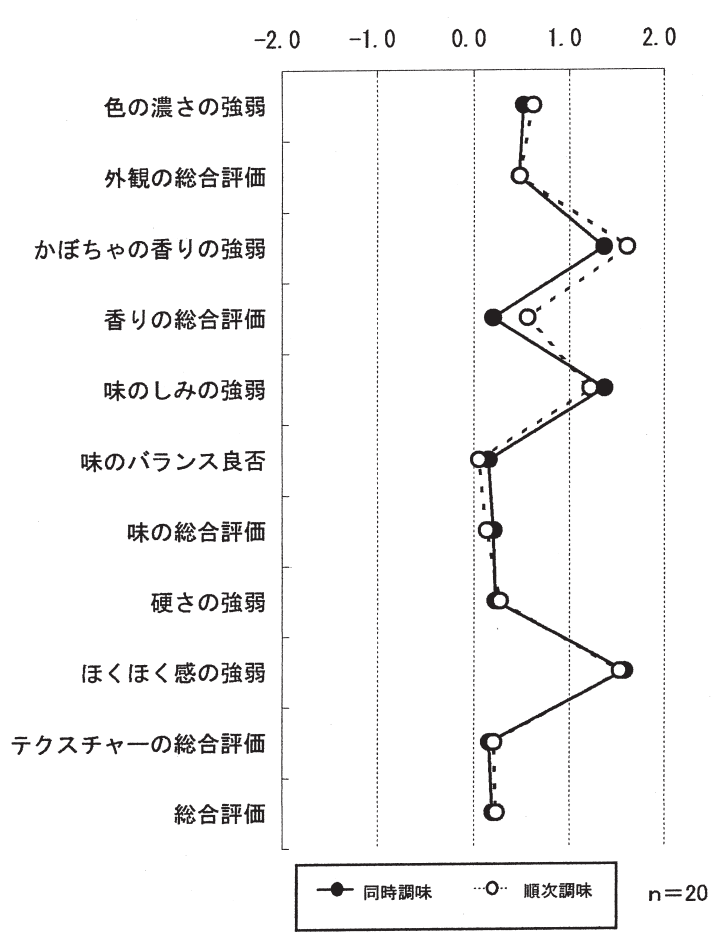

図 4 かぼちゃの含め煮

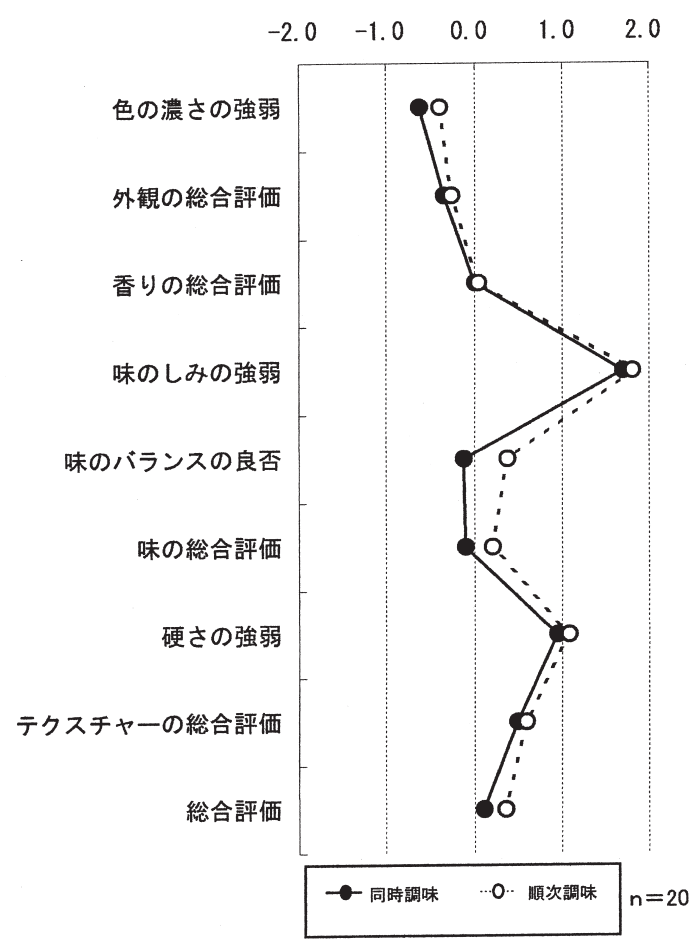

図 5 なすの炒め煮
同時調味よりも高い評価を得た。総合評価は, 順次調味 0 に対して, 同時調味はー0.5で，普通とやや悪いの間 に評価された。総合評価に有意差はないが，順次調味が 望ましいと考えられた。

\section{4 ) かぼちゃの含め煮}

官能評価の結果を図 4 に示した。全項目ともに，同時 調味, 順次調味の間には殆ど差がみられなかった。総合 評価は順次，同時調味ともに 0.2 と同值であり，かぼち
やにおいては同時調味と順次調味には殆ど差がないと思 われる。

\section{5 ）なすの炒め煮}

官能評価の結果を図 5 に示した。味のバランスの良否 において, 順次調味が同時調味よりもやや評価が高いが, その理由は, 学生では味のバランスの良否に有意差がみ られ，同時調味よりも順次調味の方が良いと評価したこ とによっている。学生の評価に抢いて味のバランスの良 
否に有意差を生じた理由はわからない。しかし，学生に 扔いても総合評価には有意差は認められなかった。総合

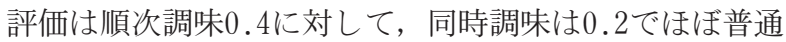
と評価されており, 同時調味で差し支えないと考えられ た。

\section{6 ）れんこんの土佐煮}

官能評価の結果を図 6 に示した。総合評価をはじめ全 ての項目に有意差は認められなかった。総合評価は順次

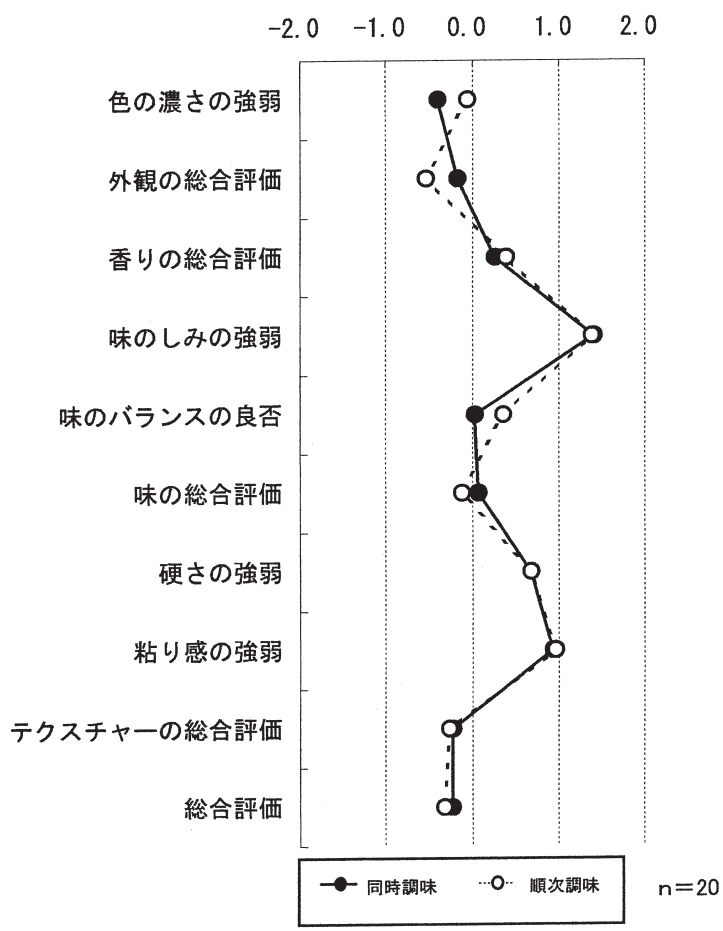

図 6 れんこんの土佐煮

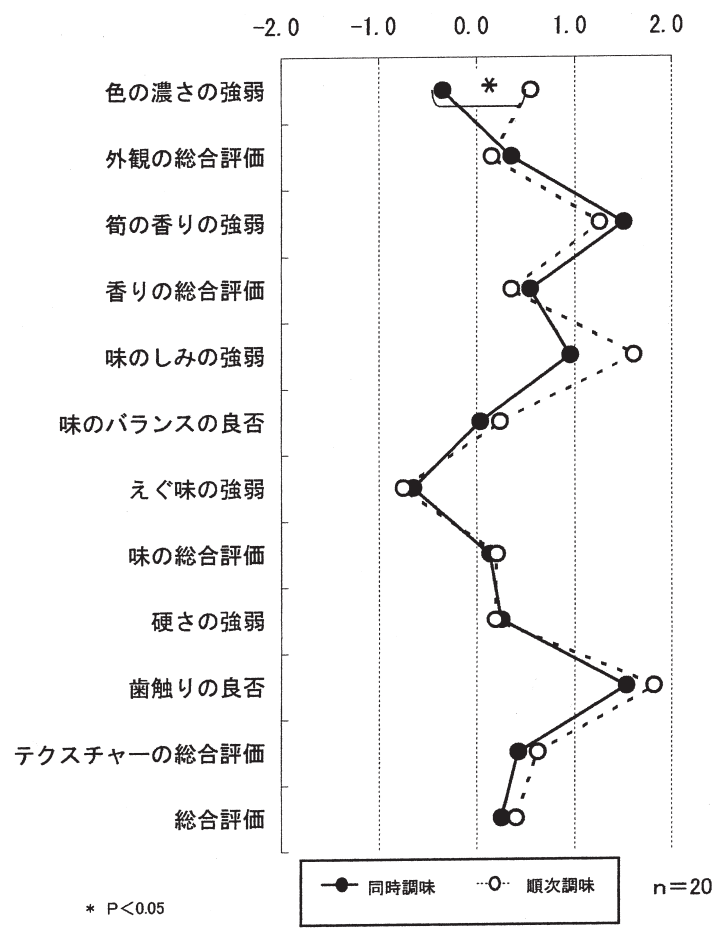

図 7 たけのこの直煮
調味-0.3に対して, 同時調味は-0.2でほぼ普通と評価 されており，同時調味で差し支えないと考えられた。

\section{7 ）たけのこの直煮}

官能評価の結果を図 7 に示した。色の濃さの強弱にお いて順次調味は同時調味に比べて $5 \%$ 危険率で有意に色 が濃いと評価されたが，外観の総合評価では有意差は認 められなかった。味の浸透の強弱においても順次調味は 同時調味よりもよく浸透していると評価されたが，味の 総合評価はほぼ同値に評価され，有意差はみられなかっ た。総合評価は順次調味 0.5 に対して, 同時調味は 0.4 と 近似し，普通とやや良いの間に評価されており，同時調 味で差し支えないと考えられた。

\section{8 ）切干だいこんの煮物}

官能評価の結果を図 8 に示した。硬さの強弱において, 順次調味が同時調味よりもやや硬いとされたが，テクス チャーの総合評価には有意差はみられなかった。総合評 価は順次調味 0.5 に対して, 同時調味は 0.2 でほぼ普通と 評価されており，同時調味で差し支えないと考えられた。

\section{9）ひじきの炒め煮}

官能評価の結果を図 9 に示した。全ての項目において 同時調味と順次調味の間にはほとんど差はみられなかっ た。総合評価は順次調味 0 に対して，同時調味は -0.1 とほぼ同值で普通と評価され，同時調味で差し支えない と考えられた。

\section{0）豚の角煮}

官能評価の結果を図10に示した。全ての項目において 順次調味と同時調味は評価が近似し，有意差は久られな かった。総合評価は共に0.4であり, 同時調味で差し支 えないと考えられた。

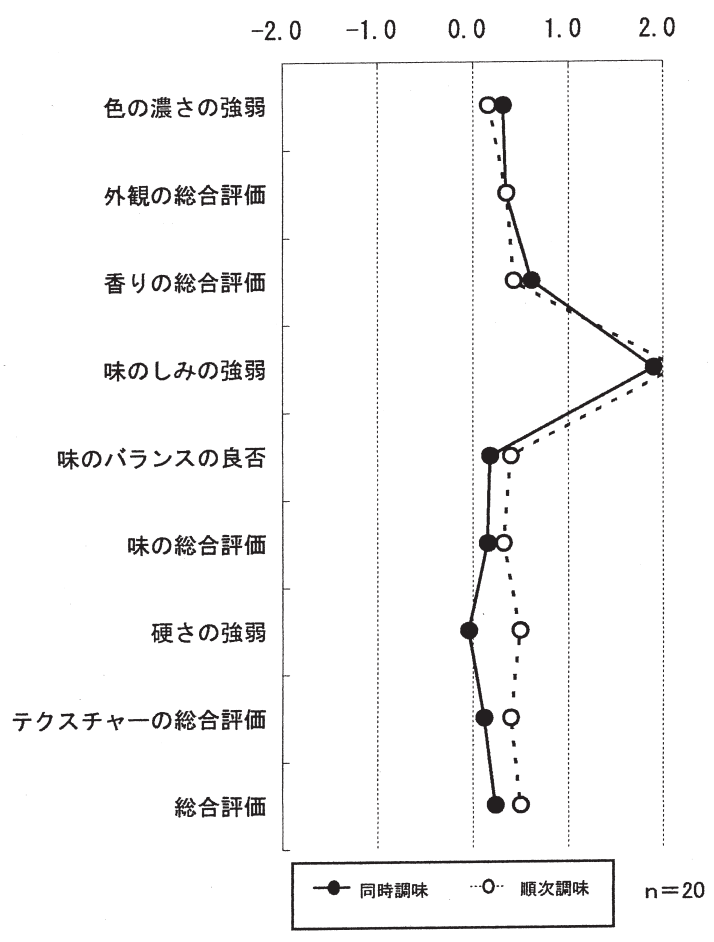

図 8 切干だいこんの煮物 


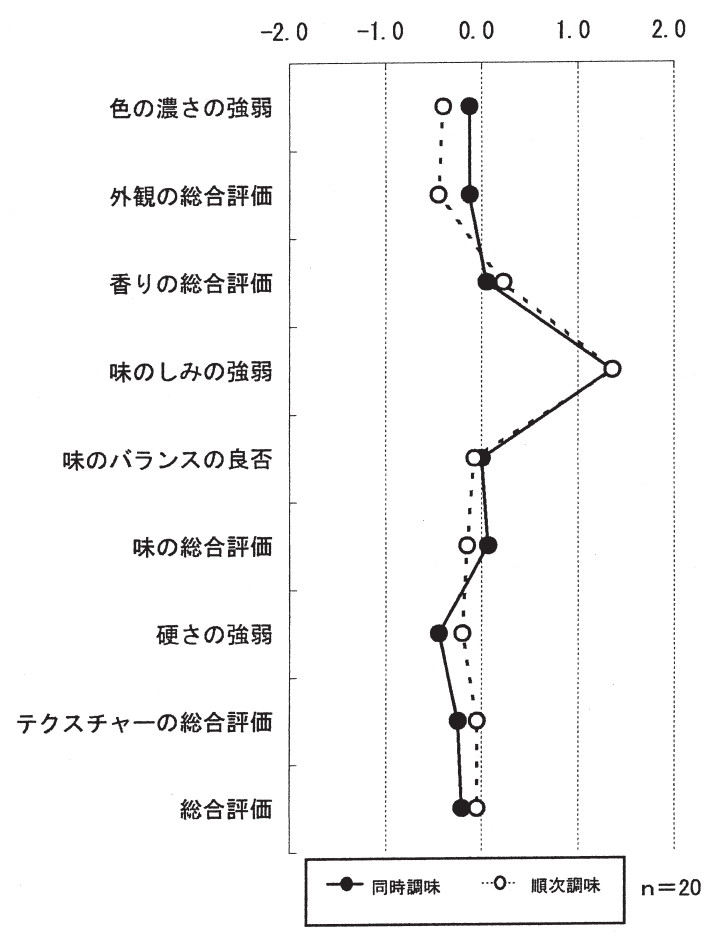

図 9 ひじきの炒め煮

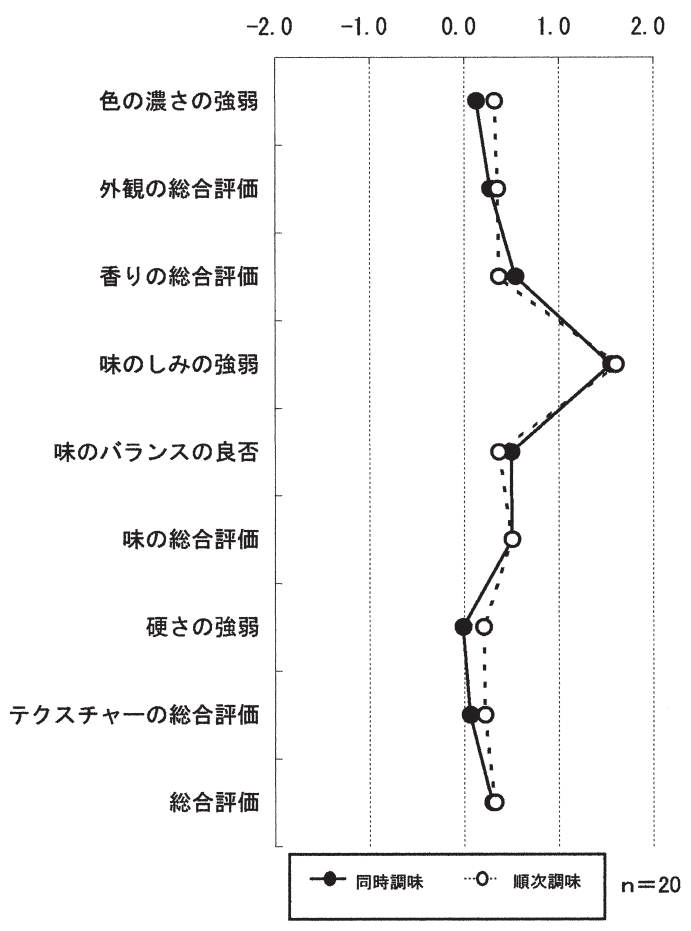

図10 豚の角煮

10種の煮物を対象に, 定法とされる順次に調味料を加 える方法と, 同時に調味料を加える方法で調理し, 官能 評価法よって外観, 香り, 味, テクスチャ一の面から差 異を検討した。その結果, 順次調味が望ましいとされた はなまめの煮物を除いては, いずれの煮物も総合評価に おいて順次調味と同時調味はほぼ同値に評価され有意差 は認められなかった。煮物に不慣れな者が煮物を難しい と考えるのは, 煮え具合と煮汁量のつり合いがとれない
ことにあるが，同時調味ならば軟らかくなるまでは調味 した煮汁を確保しつつ煮て, 軟らかくなるのを機に煮汁 を蒸発させればよく，簡便であるだけでなく失敗が少な いように思われる。

調味料の加え方については, 調味料の分子量の大小, あるいは材料を煮しめるなどの科学的根拠をもとに望を しい順序が示されてきたが，実際の調理では多くの諸条 件が絡むために, 実験における微妙な差異は感知されな いのであ万う。因及に，管見の限りでは，調味の順序に ついての記述が見られるのは昭和 20 年代以降のことで, 江戸時代の調理本や明治期の女学校の教科書などには見 当らない(19),20)。実体験からは, 順次調味の必要性を感 じることはなかったのではないかと推測される。

\section{III. 要 約}

煮物の調味は, 一般に砂糖, 食塩, しょうゆの順に時 間を打いて行われるが，調理の簡便化をはかる一法とし て調味料を 1 回にまとめて加える方法が考えられる。10 種類の煮物について, 調味料を 1 回にまとめて加える同 時調味と従来の順を追って加える順次調味で試料を調製 して, 官能評価法により比較検討し, 結果は以下のよう にまとめた。

じゃがいもの炒め煮, さといもの含め惹, かぼちゃの 含煮, なすの炒㵭, れんこんの土佐煮, たけのこの 直煮, 切干だいこんの煮物, ひじきの炒め煮, 豚肉の角 煮については, 総合評価において両方法間に有意差が認 められなかった。また総合評価值は順次調味が $-0.3 〜$ 0.5 であるのに対して, 同時調味は $-0.5 \sim 0.4$ と極めて 近い值であり, 同時調味で差し支えないと考えられた。

はなまめの煮物については, 順次調味は同時調味に比 し, つやの強弱において $1 \%$, 色の強弱において $5 \%$ の 危険率でそれぞれ強いと評価されたが，総合評価をはじ め他の評価項目においての有意差はみられなかった。し かし, いずれの評価項目に扔いても僅かながら順次調味 が同時調味よりも高い評価を得たことから，順次調味が 望ましいと考えられた。

\section{文献}

1）松本仲子, 上田フサ : 家政学会誌, 29, 351（1978）

2) 松本仲子 : 調理科学, 13, 55 (1981)

3）小川久恵, 松本仲子 : 栄養学雑誌, 40, 1, (1982)

4）小川久恵, 宮本千華子, 松本仲子 : 調理科学, 16, 242 (1983)

5）小川久恵, 宮本千華子, 松本仲子：調理科学， 20, 229 (1987)

6）松田康子, 松本仲子：日本調理科学会誌，32，37（1998）

7）松本仲子, 松田康子：日本調理科学会誌，33，58（2000）

8）松田康子, 松本仲子：日本調理科学会誌, 33, 249 (2000)

9）松本仲子, 加藤尚巳, 甲田道子, 菅原龍幸 : 家政学会誌, 40, 883 (1989)

10）松本仲子, 松田康子: 女子栄養大学栄養科学研究所年報, 2, 45 (1994) 
11）張替泰子，松本仲子：日本食生活学会誌，11，80，(2000)

12）香川芳子監修: 五訂食品成分表, p.417, 女子栄養大学出 版部 (2004)

13）香川芳子監修: 五訂食品成分表, p.416, 女子栄養大学出 版部 (2004)

14）山崎清子, 島田キミエ, 渋川祥子, 下村道子 : 新版調理 と理論, 同文書院 (2003)

15）下村道子, 中里トシ子編著：四解による基礎調理，同文
書院 (2000)

16）小川久恵 : 調理学実習テキスト, 女子栄養大学短期大学 部調理学研究室部 (2003)

17）高城順子, 松本 仲子：おかず事典, NHK 出版（1998）

18）上田フサ：上田フサの抢そうざい手ほどき, 女子栄養大 学出版部（1975）

19）赤堀峯吉: 料理の友, 大日本料理研究会（1913）

20）村上昭子 : 大正 ·昭和初期の家庭料理の本, 砂書房 (1995) 